\title{
Efficacy of Se-enriched Alga Chlorella spp. and Se-enriched Yeast on Tissue Selenium Retention and Carcass Characteristics in Finisher Pigs
}

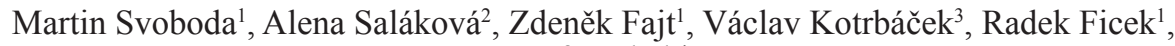 \\ Josef Drábek ${ }^{1}$
}

\begin{abstract}
${ }^{1}$ Swine Clinic, ${ }^{2}$ Department of Meat Hygiene and Technology, ${ }^{3}$ Department of Physiology University of Veterinary and Pharmaceutical Sciences Brno, Czech Republic
\end{abstract}

\author{
Received November 4, 2008 \\ Accepted March 9, 2009
}

\begin{abstract}
The aim of this study was to evaluate the effect of organic Se from Se-enriched alga (Chlorella spp.) and Se from Se-enriched yeast on concentrations of Se in serum and tissues, and serum GSH-Px activities and carcass characteristics in finishing pigs.

The pigs were on experimental diets for a period of 3 months before slaughter with different Se supplements at the concentration of $0.3 \mathrm{mg}$ Se per $\mathrm{kg}$ of feed. In group I $(\mathrm{n}=12)$ the feed was supplemented with inorganic sodium selenite; in group II $(\mathrm{n}=12)$ with organic Se from Se-enriched yeast; in group III $(\mathrm{n}=12)$ with organic Se from Se-enriched alga, Chlorella spp. and pigs in group IV $(n=11)$ received a non-supplemented basal diet. The organic Se sources did not differ in serum Se and serum GSH-Px activities. Significantly higher Se concentrations in muscle $(P<0.01)$ and in the heart $(P<0.01)$ were found when Se from Se-enriched yeast was given, compared to the group of pigs that received Se from Se-enriched alga Chlorella spp. The Se content in livers and ovaries did not differ between the two organic Se sources. The use of both organic Se forms resulted in a higher accumulation in muscle tissue compared to the inorganic Se form. No differences in meat quality characteristics were found among the experimental groups. It is concluded that Se from Se-enriched alga, Chlorella spp. had a lower accumulation in muscle tissue than Se from Se-enriched yeast, and it did not affect meat quality.
\end{abstract}

Glutathion peroxidase, GSH-Px, pork, meat quality, sodium selenite

Selenium is an essential trace element. It is involved in the enzyme glutathione peroxidase, where it works as an antioxidant protecting against oxidative stress (Muth et al. 1958; Papp et al. 2007). Its deficiency is associated with health risks for animals and humans (Nielsen et al. 1989; Pourmand et al. 2008).

Since pork is consumed throughout much of the world, it would be an excellent means of providing Se in the human diet. Meat Se concentration as well as meat quality are desirable for consumers. Both the inorganic and organic forms of Se have been used in swine production.

Studies in growing-finishing pigs have revealed that organic Se provides higher concentrations of Se in muscle tissue than the inorganic form of Se (Mahan and Parrett 1996; Mahan et al. 1999; Dokoupilová et al. 2007).

The aspect of meat quality is more complex. The antioxidants stored in the cell membrane have been suggested to have an effect on lipid oxidation and muscle cell membrane integrity, and therefore, on the kinetic of drip loss (Ashgar et al. 1989). Moreover, these antioxidants also protect myoglobin against oxidation and thus stabilize the red meat colour (Zhan et al. 2007). Therefore, enhanced antioxidant status in the muscle tends to improve meat quality by stabilizing cell membrane integrity and red meat colour. Zhan et al. (2007) found that Se supplementation to pigs decreased lipid peroxidation in muscle tissue. Studies comparing the effect of organic and inorganic Se form on pork quality have been based so far only on organic Se from Se-enriched yeast, and have brought about contradictory results (Mahan et al. 1999; Wolter et al. 1999; Mateo et al. 2007; Zhan et al. 2007). 
There is no information regarding the use of other organic Se sources in growing-finishing pigs and their effects on Se accumulation in tissues and carcass characteristics.

The freshwater alga Chlorella spp. is known for its positive effects on human health (Konishi et al. 1990; Tanaka et al. 1990). There are no data so far concerning the exact composition of seleno-amino acid analogues in Chlorella cells. The non Se-enriched biomass of Chlorella spp. has already been used by Kotrbáček et al. (1995).

The addition of alga at a relatively high level ( $7 \mathrm{~g} / \mathrm{head} /$ day) reduced the impact of preslaughter stress on meat quality. According to the authors, the exact mechanism of this phenomenon is not known but experiments on other animal species have shown that the alga increases resistance of the organism against various stress situations (Rotkovská et al. 1989; Kotrbáček et al. 1994).

Moreover, the study of Konishi et al. (1990) has demonstrated that Chlorella can be used as a potent stimulant of non-specific resistance against $E$. coli infection in rats and mice. Therefore, it could be considered a convenient carrier for organic-bound selenium in growing-finishing pigs. The aim of this study was to evaluate the effect of organic Se from Se-enriched alga (Chlorella spp.) and Se from Se-enriched yeast on concentrations of Se in serum and in tissues, on serum GSH-Px activities and carcass characteristics in finishing pigs.

\section{Materials and Methods}

Experimental conditions

A total of 47 pigs (Landrace $\times$ Czech Large White) were used in the trial. The experiment started at the beginning of the grower phase of production $(30 \mathrm{~kg}$ body weight). Before the experiment, all pigs were given the same diet supplemented with inorganic sodium selenite $(0.3 \mathrm{mg} / \mathrm{kg}$ of Se). The pigs were divided into four groups. Experimental feed mixtures were given for a three-month period. The pigs were then slaughtered and tissue samples were collected. The pigs were given feed mixtures composed of a basal diet with a mineral supplement. The mineral supplement differed in the form of Se source. During the first 30 days, the pigs were given feed mixture A1 (30-55 kg body weight). For the rest of the trial, the pigs received feed mixture A2. The pigs were fed daily $2.4 \mathrm{~kg}$ of feed per pig. The basal diet of feed mixture A1 contained $0.08 \mathrm{mg} / \mathrm{kg}$ of endogenous Se. The basal diet of feed mixture A2 contained $0.07 \mathrm{mg} / \mathrm{kg}$ of endogenous selenium.

Table 1. Percentage composition of the feed mixture A1

\begin{tabular}{|l|c|}
\hline Ingredient & Percentage \\
\hline Zeofeed (mycotoxin sorbent clinoptilolit) & 0.50 \\
Wheat & 30.40 \\
Corn & 17.00 \\
Barley & 24.00 \\
Soya bean pollard & 19.50 \\
Yeast Bitec Q & 2.00 \\
Biolac (supplemental milk mixture) & 0.80 \\
Soya bean oil & 1.30 \\
Minfos MDCP20 (monodicalciumphosphste) & 0.70 \\
Limestone & 1.40 \\
NaCl & 0.40 \\
aTrace mineral and vitamin premix & 2.00 \\
\hline
\end{tabular}

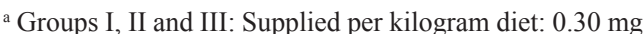
of Se, $0.50 \mathrm{mg}$ of $\mathrm{Co}, 10.00 \mathrm{mg}$ of $\mathrm{Cu}, 80.00 \mathrm{mg}$ of $\mathrm{Fe}$, $0.76 \mathrm{mg}$ of I, $30.00 \mathrm{mg}$ of Mn, $90.00 \mathrm{mg}$ of $\mathrm{Zn}, 10.00 \mathrm{mg}$ of calcium pantothenate, 7000.00 I.U. of vit. A, 1250.00 I.U. of vit. D3, $40.00 \mathrm{mg}$ of vit. E, $1.50 \mathrm{mg}$ of vit. K3, 1.50 $\mathrm{mg}$ of vit. B1, $4.20 \mathrm{mg}$ of vit. B2, $2.00 \mathrm{mg}$ of vit. B6, 0.02 $\mathrm{mg}$ of vit. B12, $15.00 \mathrm{mg}$ of niacinamid, $0.05 \mathrm{mg}$ of biotin, $0.20 \mathrm{mg}$ of folic acid, $100.00 \mathrm{mg}$ of cholinchlorid.

Group IV: without Se supplement
The composition of diets and mineral supplements are presented in Tables 1 and 2 .

In group I (12 pigs) the pigs received feed mixtures A1 and A2 supplemented with inorganic Se $(0.3 \mathrm{mg}$ $\mathrm{Se} / \mathrm{kg}$ as sodium selenite for both feed mixtures).

In Group II (12 pigs) the pigs were given diets A1 and A2 supplemented with organic selenium from Se-enriched yeast (Sel-Plex, Alltechnology CZ, s.r.o. $(0.3 \mathrm{mg} / \mathrm{kg}$ for the both feed mixtures).

Group III (12 pigs) had feed mixtures A1 and A2 supplemented with organic selenium from Seenriched alga Chlorella spp. ( $0.3 \mathrm{mg} \mathrm{Se} / \mathrm{kg}$ for the both feed mixtures). Chlorella is manufactured at the Institute of Microbiology, Czech Academy of Sciences, Třeboň. The cultivation proceeds heterotophically in fermentors on a nutrient medium containing glucose and selenite salts. The product, spray-dried biomass of disintegrated algal cell, was characterized by a high level of Se determined by an inductively coupled plasma mass spectrometry (Doucha et al. 2006).

Group IV (11 pigs) served as the negative control group. The pigs received feed mixtures A1 and A2 composed only of the basal diet.

Sampling and analysis of serum and tissues (liver, heart, ovaries, muscle tissue)

The pigs were bled from vena cava. The blood was centrifuged and serum was collected and frozen until 
Table 2. Percentage composition of the feed mixture A2

\begin{tabular}{|l|c|}
\hline Ingredient & Percentage \\
\hline Zeofeed (mycotoxin sorbent clinoptilolit) & 0.50 \\
Wheat & 34.35 \\
Corn & 15.00 \\
Barley & 24.50 \\
Soya bean pollard & 19.50 \\
Soya bean oil & 1.20 \\
Minfos MDCP20 (monodicalciumphosphste) & 0.75 \\
Limestone & 1.30 \\
NaCl & 0.40 \\
Kalama (benzoic acid) & 0.50 \\
aTrace mineral and vitamin premix & 2.00 \\
\hline
\end{tabular}

${ }^{\text {a }}$ Groups I, II, III: Supplied per kilogram diet: $0.30 \mathrm{mg}$ of $\mathrm{Se}, 0.50 \mathrm{mg}$ of $\mathrm{Co}, 10.00 \mathrm{mg}$ of $\mathrm{Cu}, 70.00 \mathrm{mg}$ of Fe, 0.76 $\mathrm{mg}$ of I, $30.00 \mathrm{mg}$ of $\mathrm{Mn}, 90.00 \mathrm{mg}$ of $\mathrm{Zn}, 9.00 \mathrm{mg}$ of calcium pantothenate, 6000.00 I.U. of vit. A, 990.00 I.U. of vit. D3, $35.20 \mathrm{mg}$ of vit. E, $1.20 \mathrm{mg}$ of vit. K3, $1.30 \mathrm{mg}$ of vit. B1, $4.20 \mathrm{mg}$ of vit. B2, $1.80 \mathrm{mg}$ of vit. B6, $0.03 \mathrm{mg}$ of vit. B12, $13.00 \mathrm{mg}$ of niacinamid, $0.05 \mathrm{mg}$ of biotin, $100.00 \mathrm{mg}$ of cholinchlorid.

Group IV: without Se supplement analyzed for GSH-Px activity and Se concentration. Concentrations of Se in serum and pig tissues (heart, liver, ovaries, and muscle tissue) were measured according to Sturman (1985) using a hydride AAS technique.

Serum GSH-Px activities were determined according to the method of Paglia and Valentin (1967) using the test kit RANSEL (Randox Laboratories, Ltd., United Kingdom).

\section{Carcass measurements}

Muscle was dissected from all pigs at $4 \mathrm{~h}$ post mortem. Muscle samples $(300 \mathrm{~g})$ were taken from musculus biceps femoris. A sample of fresh muscle tissue was subsequently cooled and stored at $4 \pm$ $2{ }^{\circ} \mathrm{C}$ for subsequent measurements.

The surface colour of raw meat was measured by the CIE L*a*b* system using Minolta CM 2600d (Konica Minolta, Japan). A measuring area of $8 \mathrm{~mm}$, illuminant D65 and $10^{\circ}$ standard observer were used. The instrument was standardized using a standard white plate. CIE L* - lightness, a* - redness, b* yellowness, Chroma $C^{*}=\left(a^{* 2}+b^{* 2}\right)^{0.5}$ and hue $\mathrm{h}^{\circ}=\tan ^{-1}\left(\mathrm{~b}^{*} / \mathrm{a}^{*}\right)$ were calculated using available software (Spectra Magic 3.61). The result stated for each sample is the mean value of ten measurements. Colours were measured $24 \mathrm{~h}$ after slaughter.

Cooking loss was analysed as [sample weight before cooking minus sample weight after cooking] $\times 100 /$ sample weight before cooking. Cooking procedure: heat treatment in plastic bags separately in water bath $\left(72{ }^{\circ} \mathrm{C}\right)$, the core temperature of samples was kept at $70{ }^{\circ} \mathrm{C}$ for $60 \mathrm{~min}$.

Drip loss was expressed as percentage of the initial weight of the meat constituted to exudates $(24 \mathrm{~h}$ after slaughter).

Ultimate $\mathrm{pH}$ (24 h after slaughter) was measured with a needle probe SenTix Sp on pH-meter 340i WTW (WTW, Germany).

The degree of lipid oxidation was measured by the reaction with thiobarbituric acid after distillation - TBA-RS value (thiobarbituric acid reactive substance) (Castellini et al. 2002).

\section{Statistical analyses}

Muscle tissue quality indicators as well as Se in serum, tissue and GSH-Px activity were tested for normal distribution in each group using Shapiro-Wilk test (Zar 1999).

All the Se indicators and others, such as weight, meat thickness, fat thickness, and meat content corresponded to normal distribution. Therefore, an analysis of variance was used to compare values in the different groups (Zar 1999). When a significant difference was found, Tukey post-hoc test for unequal sample size was used to discover the pairs of groups with different values (Spjotvoll and Stoline 1973). Other muscle tissue quality indicators ( $\mathrm{pH} 24$, loss by boiling, loss by drainage, TBA, L24, a*24, b*24, c*24, h 24) did not correspond to normal distribution. We used Kruskal-Wallis test followed by multiple comparison to determine the pairs of groups with different values (Zar 1999). Data analysis was performed using Statistica software (StatSoft Inc. 2007).

\section{Results}

\section{Se concentration in serum}

The concentrations of Se in serum were found to be comparable among the experimental groups at the beginning of the trial (Fig. 1). No differences among the Se-supplemented groups of pigs (group I, II, III) were found prior to slaughter. Se concentrations before slaughter in the group of pigs given diets with no supplemental Se (group IV) were significantly lower than in the supplemented groups $(P<0.01)$

\section{GSH-Px activity in serum}

No differences in GSH-Px activities were found among any of the experimental groups at the beginning of the study (Fig. 2). Before the slaughter, GSH-Px activities were comparable 


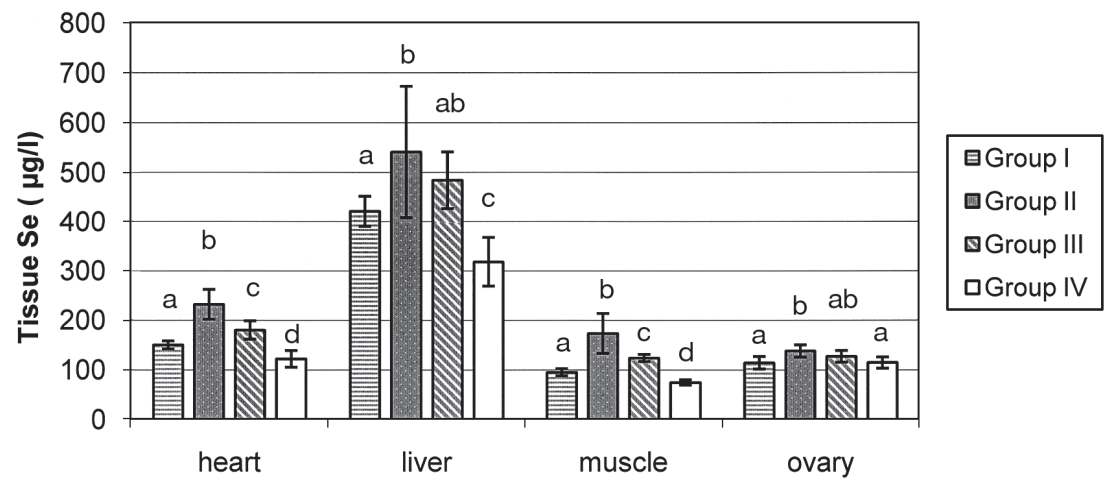

Fig 1. Se concentration in serum $(P<0.05)$

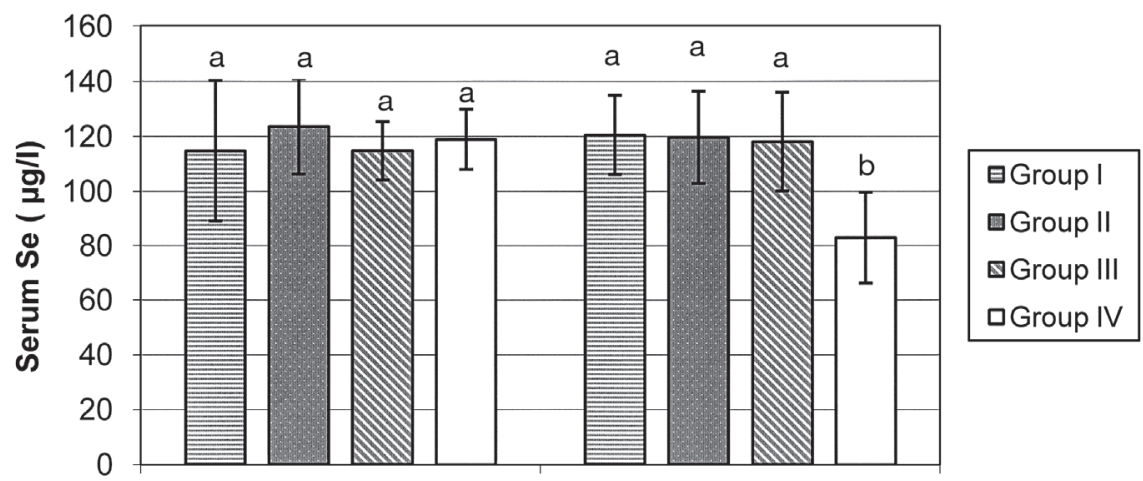

Fig 2. GSH-Px activities in serum $(P<0.05)$

among the Se supplemented groups and significantly lower in Se non-supplemented group $(P<0.05)$.

Se concentration in tissues

Comparison of organic and inorganic Se forms

In the group of pigs fed organic Se from Se-enriched yeast, the Se concentration in all tissues was significantly higher $(P<0.01)$ compared to the groups that received the inorganic Se form (Fig. 3).

The pigs given Se from Se-enriched alga had significantly higher concentrations of Se in the heart $(P<0.01)$ and muscle $(P<0.05)$ compared to pigs that received the inorganic Se source. Se content in the liver and ovaries did not differ between Se from alga and the inorganic Se source.

Comparison of the two organic sources

We found significantly higher Se concentrations in muscle $(P<0.01)$ and heart tissue $(P<0.01)$ when Se from Se-enriched yeast was given, compared to the group of pigs that received Se from Se-enriched alga Chlorella spp. Se content in the liver and ovaries did not differ between the two organic Se sources. 


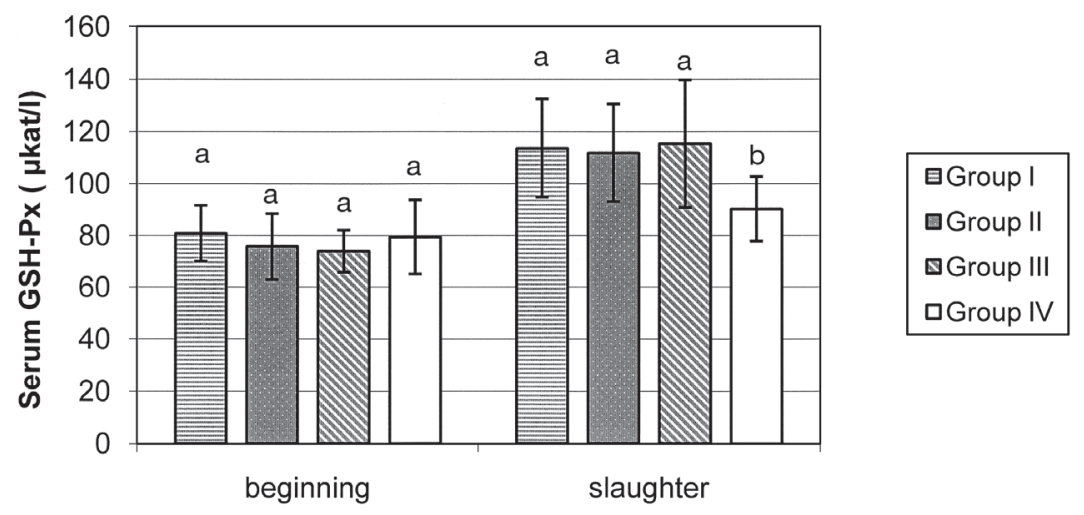

Fig 3. Se concentration in tissues $(P<0.05)$

Comparison of Se-supplemented and Se-non supplemented diets

Se concentration in the liver, heart and muscle tissues of Se in the non-supplemented group of pigs was significantly lower compared to the Se-supplemented groups $(P<$ $0.01)$. Se content in the ovaries in the non-supplemented group was significantly lower compared to the group given Se from Se-enriched yeast $(P<0.01)$ and did not differ from the groups of pigs supplemented with Se from Se-enriched alga and with the inorganic Se form.

Carcass measurements and meat quality

No differences were found in major carcass measurements such as hot weight, percentage of lean tissue, fat thickness (Table 3). No significant differences were found in colour characteristics $\left(\mathrm{L}^{*}, \mathrm{a}^{*}, \mathrm{~b}^{*}, \mathrm{C}^{*}, \mathrm{~h}^{\circ}\right)$ or the $\mathrm{pH}$ value of the meat among the experimental groups. There were no significant differences in cooking loss and drip loss. Evaluating lipid oxidation, the TBA-RS value was lower in group III, but the differences were not significant.

Table 3. Muscle characteristics

\begin{tabular}{|l|r|r|r|c|}
\hline & $\begin{array}{c}\text { Group I } \\
\text { Mean } \pm \text { SD }\end{array}$ & $\begin{array}{c}\text { Group II } \\
\text { Mean } \pm \text { SD }\end{array}$ & $\begin{array}{c}\text { Group III } \\
\text { Mean } \pm \text { SD }\end{array}$ & $\begin{array}{c}\text { Group IV } \\
\text { Mean } \pm \text { SD }\end{array}$ \\
\hline Hot weight (kg) & $78.57 \pm 7.11$ & $78.49 \pm 4.96$ & $79.00 \pm 5.12$ & $82.79 \pm 4.82$ \\
\hline Meat thickness (mm) & $62.80 \pm 4.05$ & $65.44 \pm 4.39$ & $64.25 \pm 7.15$ & $63.88 \pm 4.82$ \\
\hline Fat thickness (mm) & $15.50 \pm 3.34$ & $14.56 \pm 3.36$ & $15.08 \pm 3.50$ & $15.38 \pm 3.46$ \\
\hline $\begin{array}{l}\text { Percentage of lean } \\
\text { muscle (\%) }\end{array}$ & $56.62 \pm 2.48$ & $57.67 \pm 2.38$ & & $56.86 \pm 3.07$ \\
\hline pH & $5.66 \pm 0.17$ & $5.60 \pm 0.10$ & $5.68 \pm 2.23$ & $5.67 \pm 0.07$ \\
\hline Cooking loss (\%) & $34.00 \pm 2.45$ & $34.78 \pm 1.96$ & $35.06 \pm 0.08$ & $33.53 \pm 1.72$ \\
\hline Drip loss (\%) & $2.80 \pm 0.61$ & $3.21 \pm 0.72$ & $3.15 \pm 1.85$ & $3.00 \pm 0.67$ \\
\hline TBA-RS (mg/kg) & $1.46 \pm 0.52$ & $1.50 \pm 0.50$ & $1.22 \pm 0.72$ & $1.39 \pm 0.38$ \\
\hline $\mathrm{L}^{*}$ & $54.13 \pm 3.68$ & $54.55 \pm 3.63$ & $52.17 \pm 0.39$ & $52.36 \pm 2.65$ \\
\hline $\mathrm{a}^{*}$ & $1.61 \pm 1.55$ & $1.77 \pm 1.30$ & $1.43 \pm 4.09$ & $1.66 \pm 1.78$ \\
\hline $\mathrm{b}^{*}$ & $9.55 \pm 0.72$ & $9.42 \pm 0.77$ & $8.90 \pm 1.19$ & $8.82 \pm 1.19$ \\
\hline $\mathrm{C}^{*}$ & $9.80 \pm 0.90$ & $9.66 \pm 0.83$ & $9.10 \pm 0.84$ & $8.94 \pm 1.58$ \\
\hline $\mathrm{h}^{\circ}$ & $83.00 \pm 9.14$ & $81.98 \pm 10.19$ & $82.78 \pm 9.56$ & $80.24 \pm 9.02$ \\
\hline
\end{tabular}

$\mathrm{L}^{*}$ - lightness, $\mathrm{a}^{*}$ - redness, $\mathrm{b} *$-yellowness, $\mathrm{C}^{*}-\mathrm{Chroma}^{\circ} \mathrm{h}^{\circ}$ - colour hue 


\section{Discussion}

It is generally accepted that selenomethionine (SeMet) represents the principal part of seleno-amino acid analogues in Chlorella cells. However, the exact composition and percentage of seleno-amino acid analogues is not yet known. Therefore, experiments with the use of Se-enriched Chlorella in animals can bring about useful additional information. The alga cells are enriched with selenium by cultivation in a medium containing selenite salts. The alga cells are then disintegrated and digestible biomass is obtained (Doucha et al. 2006). Fractionation by the use of plasma mass spectrometry provides information on a high portion of the organic form of Se (Doucha et al. 2006).

According to Schrauzer (2000), Se-enriched yeast contains $90 \%$ of the total Se in the form of SeMet and additional organic selenium compounds (selenocystein, selenocystathionine, methylselenocystein, glutamyl-Se-methylselenocysteine and Seadenosyl-selenohomocysteine).

At the dietary level of $0.3 \mathrm{mg} \mathrm{Se} / \mathrm{kg}$, we found no differences in serum Se and serum GSH-Px activities between the organic and inorganic Se sources. This is in agreement with Mahan and Parrett (1996) and Mahan et al. (1999). According to Mahan and Parrett (1996), serum concentrations were lower at $0.1 \mathrm{mg} \mathrm{Se} / \mathrm{kg}$ when Se-enriched yeast was given, but statistically comparable concentrations were obtained at higher dietary levels. Mahan and Parrett (1996) also reported that serum GSH-Px activity tended to be lower at the $0.1 \mathrm{mg} / \mathrm{kg}$ dietary Se level when Se-enriched yeast was provided when compared to sodium selenite, but statistically comparable GSH-Px activities were apparent at the $0.3 \mathrm{mg} / \mathrm{kg}$ dietary Se level. Statistically comparable serum GSH-Px activities between the organic and inorganic Se source indicate that only part of selenomethionine was adopted for selenoprotein synthesis, and the rest was stored as selenomethionine in substitution for methionine in tissues (Zhan et al. 2007).

Our results indicate that the bioavailability of Se from Se-enriched alga was high and when compared to the inorganic form, resulted in significantly higher concentrations of Se in the muscle tissue. The supplement of Se from Se-enriched Chlorella was used by Ševčíková et al. (2006) in the diet for broiler chickens. Its use increased the Se concentration in muscle tissue. Selenium-enriched Chlorella was used also as a selenium supplement in laying hens (Skřivan et al. 2006). The use of Se-enriched Chlorella resulted in increased egg white and egg yolk Se content compared to sodium selenite.

We suggest that the effectiveness of Se from Se-enriched alga can be explained by the high bioavailability of selenomethionine. Ingested Se-met is absorbed in the small intestine. Semet is activated initially by adenosylation, demethylated, and then converted to Se-cys via selenohomocysteine and selenocystathionine. The selenocysteine form is degraded further in the liver to serine and selenide. Selenide is finally used for selenoprotein synthesis, such as GSH-Px. Any Se-met that is not immediately metabolized is incorporated into organs with high rates of protein synthesis such as skeletal muscle. Sodium selenite is converted initially to selenoglutathione trisulfate and then degraded in liver to form selenide (Schrauzer 2000; Suzuki and Ogra 2002). Although inorganic selenite can be utilized for selenoprotein biosynthesis, only selenomethionine is incorporated non-specifically by body proteins in place of methionine (McConnel and Hoffman 1972).

In our experiment, the Se concentration in muscle tissue from the group of pigs supplemented with Se from Se-enriched yeast was superior to that of pigs fed with Se from Se-enriched alga. This is in agreement with the findings of Ševčíková et al. (2006) in broiler chickens where higher values in muscle tissue were measured in the group supplemented with Se from Se-enriched yeast than in the group provided with Se from Seenriched Chlorella. According to Schrauzer (2000) the utilization of Se can be influenced by the composition of seleno-amino acid analogues. Moreover, the percentage of soluble 
and non-soluble organic fractions and non-metabolised selenite can also play a role. Further studies are needed to fully characterize the composition of seleno-amino acid analogues in alga Chlorella spp.

Se concentrations in tissues in the non-supplemented group were lower than in the supplemented groups. This was consistent with previous reports (Kurkela and Kaäntee 1984; Mahan and Parrett 1996; Mateo et al. 2007). However, Se concentration in ovaries from the non-supplemented group was comparable to the group of pigs that had been given inorganic Se. We suggest that this could be due to the preferential deposition of Se into the reproductive tissues. According to Bates et al. (2000), a regulatory mechanism exists to conserve Se in critical tissues. They found that the cerebrum, and the thyroid and pituitary glands from Se-deficient rats exhibited a marked decrease in Se levels than did the liver. In contrast to our study, Se concentration in the ovaries showed a substantial decrease $(62 \%)$ in Se-deficient rats. The reason for this difference is not clear, but a more insufficient diet $(5 \mu \mathrm{g} \mathrm{Se} / \mathrm{kg})$ was used in the study of Bates et al. (2000).

As far as the indices of meat quality are concerned, there are many discrepancies in the available literature. No differences in major carcass measurements were found between the groups (hot weight, fat thickness, percentage of lean tissue). These findings are in agreement with Wilkinson et al. (1977), Mahan et al. (1999) and Mateo et al. (2007), and confirm that major carcass measurements are not affected by the dietary Se source.

In our study, no differences in other indices of meat quality were found. This is in agreement with Wolter et al. (1999) who found that the Se source did not affect meat quality. On the contrary, Mahan et al. (1999) and Mateo et al. (2007) reported that inorganic Se could possibly have a detrimental effect on pork quality, as reflected by a higher drip loss and a paler colour. Mahan et al. (1999) and Mateo et al. (2007) also reported that organic Se did not affect pork quality.

On the other hand, Zhan et al. (2007) reported that selenomethionine stabilizes the red colour of the meat and also reduces drip loss by enhancing its antioxidant ability. According to Padmaja et al. (1996) and Sies and Arteel (2000), the antioxidant property of selenomethionine is related to its capacity to act as a scavenger of strong oxidant peroxynitrite. The degree of lipid oxidation of muscle tissue is evaluated by determination of malonaldehyde content (TBA-value). Zhan et al. (2007) found that compared to Sedeficient group, Se supplementation decreased significantly the MDA content in muscle tissue. This indicates a Se-enhanced muscle antioxidant ability to protect against lipid peroxidation. In our study, we did not find significant differences between Se-supplemented and Se-deficient groups. We suggest that this difference can be explained by the fact that Zhan et al. (2007) used a basal diet with a lower Se content $(0.045 \mathrm{mg} / \mathrm{kg}$ of Se). Zhan et al. (2007) also reported that the content of MDA in muscle tissue in selenomethioninetreated group was lower than in sodium selenite treated group. This indicates that selenomethionine improved the ability to protect against oxidation. Also in our experiment lipid oxidation according to TBA value was the lowest in Chlorella-supplemented group, but the difference was not significant.

We conclude that the use of Se from Se-enriched alga Chlorella spp. results in a lower accumulation of Se in muscle tissue compared to Se from Se-enriched yeast and did not influence the meat-quality characteristics.

\section{Vliv selenem obohacené řasy Chlorella spp. a selenem obohacenych kvasnic na akumulaci selenu v tkáních a na ukazatele kvality masa u výkrmových prasat}

Cílem této práce bylo zhodnotit účinky organické formy selenu ze selenem obohacené řasy (Chlorella spp.) a selenu ze selenem obohacených kvasnic na koncentraci selenu v séru a tkáních, na aktivitu GSH-Px v séru a na ukazatele kvality masa u výkrmových prasat. Po 
dobu 3 měsíců před porážkou byla prasata krmena různými doplňky selenu o koncentraci $0.3 \mathrm{mg} / \mathrm{kg}$ krmiva. Ve skupině I $(\mathrm{n}=12)$ bylo krmivo obohaceno anorganickým seleničitanem sodným; ve skupině II $(n=12)$ organickým selenem ze selenem obohacených kvasnic; ve skupině III $(\mathrm{n}=12)$ organickým selenem ze selenem obohacené řasy Chlorella spp. a prasata ve skupině IV $(\mathrm{n}=11)$ dostávala neobohacenou dietu. Organické formy selenu se v sérových hladinách Se a aktivitě GSH-Px nelišily. Prokazatelně vyšší koncentrace selenu ve svalech $(P<0.01)$ a srdci $(P<0.01)$ byly nalezeny u skupiny, kde byl podáván Se ze selenem obohacené řasy, Chlorella spp. V játrech a vaječnících se obsah selenu mezi oběma formami nelišil. Použití obou organických forem způsobuje vyšší akumulaci Se ve svalové tkáni, než je tomu při použití anorganické formy. Mezi pokusnými skupinami nebyly zaznamenány žádné výrazné rozdíly v kvalitě svaloviny. Lze konstatovat, že selen pocházející ze selenem obohacené řasy Chlorella spp. vykazuje nižší akumulaci ve svalové tkáni, než Se ze selenem obohacených kvasnic, a neovlivňuje ukazatele kvality masa.

\section{Acknowledgements}

The study was supported by the projects MSM 6215712403 and MSM 6215712402.

\section{References}

Ashgar V, Lin CF, Booren AM, Crackel R, Flekal CJ 1989: Influence of oxidized dietary oil and antioxidant supplementation on membrane-bound stability in broiler meat. Br Poultry Sci 30: 815

Bates JM, Spate VL, Morris JS, ST. Germain DL, Galton VA 2002: Effects of Selenium Deficiency on Tissue Selenium Content, Deiodinase Activity, and Thyroid Hormone Economy in the Rat during Development. Endocrinology 141: 2490-2500

Castellini C, Mugnai C, Dal Bosco A 2002: Effect of organic production system on broiler carcass and meat quality. Meat Science 60: 219-225

Doucha J, Livanský K, Kotrbáček V, Machát J 2006: Production of Chlorella biomass enriched by selenium and its use as a feed supplement. $6^{\text {th }}$ Asia-Pacific conference on algal biotechnology, Manila, Philippines, pp. $143-144$

Dokoupilová A, Marounek M, Skřivanová V, Březina P 2007: Selenium content in tissues and meat quality in rabbits fed yeast. Czech J Anim Sci 52: 165-169

Konishi F, Tanaka K, Kumamoto S, Hasegawa T, Okuda M, Yano I, Yoshikai Y, Nomoto K 1990: Enhanced resistance against Escherichia coli infection by subcutaneous administration of hot-water exctract of Chlorella vulgaris in cyclophosphamide-treated mice. Cancer Immunol Immunother 32: 1-7

Kotrbáček V, Halouzka R, Jurajda V, Knotková Z, Filka J 1994: Zvýšení obranyschopnosti brojlerů po podávání biologických krmných doplňků. Vet Med-Czech 39: 321-328

Kotrbáček V, Ingr I, Filka J, Dvořák J 1995: The effect of application of the alga Chlorella vulgaris on the occurence of the pork defects. Živočišná výroba 40: 519-522

Kurkela P, Kääntee E 1984: Effects of barley-bound organic selenium compared with inorganic selenium on selenium concentration and structure of tissues in pig. J Agric Sci Finl 56: 61-72

Mahan DC, Clone TR, Richert B 1999: Effects of dietary levels of Se-enriched yeast and sodium selenite as Se source fed to growing-finishing pigs on performance, tissue glutathione peroxidase activity, carcass characteristics and loin quality. J Anim Sci 77: 2172-2179

Mahan DC, Parrett NA 1996: Evaluating the efficacy of Se enriched yeast and inorganic selenite on tissue retention and serum glutathione peroxidase activity in grower finisher swine. J Anim Sci 74: 2967-2974

Mateo RD, Spallholz JE, Doder R, Yoon I, Kim SW 2007: Efficacy of dietary selenium source on growth and carcass characteristics of growing-finishing pigs fed diets containing high endogenous selenium. J Anim Sci 85: $1177-1183$

McConnell KP, Hoffman JL 1972: Methionine-selenomethionine parallels in rat liver polypeptide chain synthesis. Fed Proc 31: 691

Muth OH, Oldfield JE, Remmert LF, Schubert JR 1958: Effects of selenium and vitamin E on white muscle disease. Science 128: 1090-1090

Padmaja S, Squadrito GL, Lemercier JN, Cueto R, Pryor WA 1996: Rapid oxidation of DL-selenomethionine by peroxynitrite. Free Radical Biol Med 21: 317-322

Paglia DE, Walentine WN 1967: Studies on the quantitative and qualitative characterization of erythrocytes glutatione peroxidase. J Lab Clin Med 70: 158-169

Papp LV, Lu J, Holmgren A, Khanna KK 2007: From selenium to selenoproteins: Synthesis, Identity and Their Role in Human Health. Antioxidants and Redox Signaling 9: 775-806

Pourmand G, Salem S, Moradi K, Nikoobakht MR, Tajik P, Mehrsai A 2008: Serum Selenium Level and Prostate Cancer: A Case-Control Study. Nutrition and Cancer 60: 171-176 
Rotkovská D, Vacek A, Bartoníčková A 1989: The radioprotective effects of aqueous extract from chlorococcal freshwater algae (Chlorella kessleri) in mice and rats. Stralenther Onkol 165: 813-816

Schrauzer GN 2000: Selenomethionine: a review of its nutritional significance, metabolism and toxicity. J Nutr 130: $1653-1656$

Suzuki KT, Ogra Y 2002: Metabolic pathway for selenium in the body: speciation by HPLC-ICP MS with enriched Se. Food Addit. Contam 19: 974-983

Ševčíková S, Skřivan M, Dlouhá G, Koucký M 2006: The effect of selenium source on the performance and meat quality of broiler chickens. Czech J Anim Sci 51: 449-457

Sies H, Arteel G 2000: Interaction of peroxynitrite with selenoproteins and glutatione peroxidase mimics. Free Radical Biol Med 28: 1451-1455

Skřivan M, Šimáně J, Dlouhá G, Doucha J 2006: Effect of dietary sodium selenite, Se-enriched yeast and Seenriched Chlorella on egg Se concentration, physical parameters of eggs and laying hen production. Czech J Anim Sci 51: 163-167

Spjotvoll E, Stoline MR 1973: An extension of the T-method of multiple comparison to include the cases with unequal sample sizes. J Amer Stat Assoc 68: 976-978

StatSoft, Inc. (2007) STATISTICA (data analysis software system), version 8.0. www.statsoft.com

Sturman BT 1985: Development of a continuous-flow hybride and mercury vapor generation accessory for atomic absorption spectrophotometry. Appl Spectroscopy 39: 48-56

Wilkinson JE, Bell MC, Bacon JA, Melton CC 1977: Effects of supplemental selenium on swine. II. Growingfinishing. J Anim Sci 44: 229-233

Wolter B, Ellis M, McKeith FK, Miller KD, Mahan DC 1999: Influence of dietary selenium source on growth performance, and carcass and meat quality characteristics in pigs. Can J Anim Sci 79: 119-21

Zar JH 1999: Biostatistical Analysis (4 ${ }^{\text {th }}$ ed.). Prentice Hall, New Jersey

Zhan XA, Wang M, Zhao RQ, Li WF, Xu ZR 2007: Effects of different selenium source on selenium distribution, loin quality and antioxidant status in finishing pigs. Anim Feed Sci and Tech 132: 202-211 
